\title{
Pengelompokkan Provinsi Berdasarkan Variabel Kesehatan Lingkungan Dan Pengaruhnya Terhadap Kemiskinan Di Indonesia Tahun 2018
}

\author{
Tri Rena Mayasari ${ }^{*}$ \\ ${ }^{1}$ Fungsional Statistisi Pertama BPS Kabupaten Pesawaran \\ J1. Ahmad Yani No 119, Geong Tatan, Pesawaran, Lampung \\ *Email korespondensi: tri.mayasari@bps.go.id \\ Dikirim: 13-02-2020, Diterima: 17-03-2020, Diterbitkan: 31-03-2020
}

\begin{abstract}
Abstrak
Indikator kesehatan lingkungan merupakan faktor penting yang dapat berdampak bagi kesehatan dan perekonomian negara. Indonesia merupakan negara dengan ketimpangan pada tingkat kemiskinan dan indikator kesehatan lingkungan. Paper ini mengkaji pengaruh kesehatan lingkungan terhadap tingkat kemiskinan yang terjadi di Indonesia dengan pendekatan model regresi linier berganda. Selanjutnya berdasarkan indikator kesehatan lingkungan dilakukan pengelompokan provinsi melalui metode Hierarchical Cluster agar dapat melihat provinsi mana yang perlu diperhatikan guna mempercepat pencapaian Tujuan Pembangunan Berkelanjutan atau Sustainable Development Goals (SDGs). Hasil penelitian menunjukkan bahwa hanya variabel fasilitas sanitasi layak yang siginifikan memengaruhi tingkat kemiskinan di Indonesia. Namun, konstanta variabel hunian layak lebih cepat untuk menurunkan tingkat kemiskinan dibandingkan variabel lainnya. Selain itu, berdasarkan kriteria indikator kesehatan lingkungan, ada 3 provinsi dikategorikan rendah, 7 provinsi termasuk kategori tinggi dan sisanya 24 provinsi berkategori sedang. Provinsi Bengkulu, Lampung dan Papua merupakan provinsi yang memiliki indikator kesehatan lingkungan dan tingkat kemiskinan terburuk dibandingkan dengan provinsi lainnya sehingga perlu mendapat perhatian lebih dari pemerintah pusat.
\end{abstract}

Kata kunci : kelompok, kemiskinan, kesehatan lingkungan

\begin{abstract}
Environmental health indicators are important factors that can affect the health and economy of the country. Indonesia is a country with inequality in poverty levels and environmental health indicators. This paper examines the effect of environmental health on poverty levels occurring in Indonesia with the multiple linear regression model approach. Furthermore, based on environmental health indicators the grouping of provinces is done through the Hierarchical Cluster method in order to see which provinces need to be considered in order to accelerate the achievement of the Sustainable Development Goals (SDGs). The results show that only the variable of appropriate sanitation facilities significantly affected poverty levels in Indonesia. However, the constant variable occupancy deserves faster to reduce poverty than the other variables. In addition, based on the criteria for environmental health indicators, there are 3 provinces categorized as low, 7 provinces included in the high category and the remaining 24 provinces are categorized as medium. The provinces of Bengkulu, Lampung and Papua are provinces that have the worst indicators of environmental health and poverty levels compared to other provinces so they need more attention from the central government.
\end{abstract}

Keywords: environmental health, groups, poverty

\section{Pendahuluan}

Kesehatan lingkungan yang tidak memadai berdampak negatif bagi kesehatan dan ekonomi negara termasuk di Indonesia. Belajar dari krisis ebola di Afrika Barat, WHO menyatakan bahwa kesehatan lingkungan yang terdiri dari akses sanitasi layak, akses air bersih, dan layanan kebersihan yang memadai berperan penting mencegah penyakit wabah sekaligus mengendalikan infeksi [1].

"Lingkungan yang baik terbukti bisa mencegah terjadinya kontaminasi pada sumber air bersih, melindungi lingkungan, mencegah penyakit menular, serta membantu mengurangi malnutrisi, stunting, dan terhambatnya perkembangan mental anak," tutur Dr Poonam Khetrapal Singh, Direktur Regional WHO di Asia Tenggara. 
Dalam artikel [2] disebutkan bahwa kesehatan lingkungan dapat dipengaruhi oleh 3 faktor resiko utama, yaitu air dan sanitasi yang tidak aman, polusi udara dalam ruangan akibat penggunaan bahan bakar padat, dan polusi udara di luar ruangan. Penelitian tersebut juga menunjukkan bahwa kondisi lingkungan memengaruhi kesehatan dan ekonomi pada suatu negara. Negara yang memiliki kondisi lingkungan yang baik cenderung memiliki tingkat kesehatan dan ekonomi yang baik pula. Oleh karena itu, penting untuk menjaga kesehatan lingkungan.

Kesehatan lingkungan menurut Peraturan Pemerintah Republik Indonesia Nomor 66 Tahun 2014 tentang kesehatan lingkungan didefinisikan sebagai upaya pencegahan penyakit dan atau gangguan kesehatan dari faktor resiko lingkungan untuk mewujudkan kualitas lingkungan yang sehat baik dari aspek fisik, kimia, biologi, maupun sosial. Peraturan tersebut juga menyebutkan bahwa standar baku mutu kesehatan lingkungan dan persyaratan kesehatan ditetapkan pada media lingkungan yang meliputi : air, udara, tanah, pangan, sarana dan bangunan serta vektor dan binatang pembawa penyakit. Dengan demikian, kesehatan lingkungan dapat dilihat dari adanya air minum layak, sanitasi layak dan adanya rumah layak huni.

Indonesia merupakan salah satu negara yang ikut berkomitmen dalam tujuan pembangunan berkelanjutan atau Sustainable Development Goals (SDGs). Dalam komitmen tersebut, Indonesia menyepakati 17 komitmen SDGs akan terlaksana sampai dengan tahun 2030. Bahkan 17 komitmen SDGs tersebut tertuang dalam RPJMN 2015-2019 dengan target bahwa tujuan SDGs tersebut dapat tercapai pada tahun 2019. Tak terkecuali pada tujuan SDGs yang keenam yaitu akses air bersih dan sanitasi layak dengan agenda program nasional 100\% akses universal air minum dan sanitasi layak pada tahun 2019.

Pada kenyataannya,pada tahun 2018 hanya rumah layak huni yang hampir tercapai 100 persen. Sedangkan untuk akses air bersih dan sanitasi layak masih berada pada capaian yang memprihatinkan. Pada tahun 2016, capaian air minum layak di Indonesia baru mencapai 71,14 persen, kemudian meningkat 72,04 persen pada tahun 2017 dan 73,68 persen pada tahun 2018. Dengan demikian, rata-rata kenaiakan capaian air minum layak secara Nasional hanya sebesar 1 persen setiap tahunnya, sehingga hal tersebut sangatlah sulit untuk dapat tercapai pada tahun 2019. Selain itu, Indonesia juga memiliki rapor buruk pada hal sanitasi. Pada tahun 2016, akses sanitasi layak di Indonesia sebesar 67,80 persen; kemudian meningkat menjadi 67,89 persen pada tahun 2017 dan kembali meningkat menjadi 69,27 persen pada tahun 2018 [1].

Rendahnya akses air minum dan sanitasi layak di Indonesia merupakan adanya dampak ketimpangan dan kesenjangan yang terjadi di Indonesia, khususnya pada daerah Indonesia Bagian Barat dan Indonesia Bagian Timur. Di Provinsi Papua misalnya, setengah dari penduduknya memiliki akses air minum yang tak layak dan dua diantara tiga rumah tangga memiliki akses sanitasi yang buruk. Sedangkan di Ibukota yaitu Provinsi DKI Jakarta, lebih dari 90 persen rumah tangga telah memiliki akses air minum dan sanitasi yang layak.

Melihat adanya kesenjangan dan ketimpangan seperti hal di atas, diperlukan pengkajian mendalam terkait indikator kesehatan lingkungan yang dapat dilihat dari variabel akses air minum layak, sanitasi layak dan rumah layak huni. Kemudian, dari ketiga variabel tersebut, perlu adanya pengkajian lebih lanjut untuk melihat keterkaitannya dengan kemiskinan yang ada di Indonesia. Dengan demikian dapat ditelusuri kelompok provinsi mana yang perlu diperhatikan guna mendorong dan mempercepat target pencapaian kesehatan lingkungannya. Pada artikel ini dikaji analisis provinsi mana yang perlu dipercepat untuk pencapaian indikator kesehatan lingkungan dan untuk melihat keterkaitan indikator kesehatan lingkungan dengan kemiskinan yang ada di Indonesia. Oleh karena itu, sangat penting memerhatikan pengelompokkan provinsi di Indonesia berdasarkan indikator kesehatan lingkungan dan kaitannya dengan kemiskinan di Indonesia.

Ada beberapa metode pengelompokan (clustering) yang diaplikasikan di bidang berbeda pada penelitian terdahulu diantaranya hierarchical clustering [4], partitional clustering yaitu metode k-means [5], two stage clustering [6] dan fuzzy c-means [7]. Dalam paper ini, akan dilakukan analisis cluster untuk mengelompokkan Provinsi di Indonesia berdasarkan tiga variabel pembentuk indikator kesehatan lingkungan menggunakan hierarchical clustering. Kemudian digunakan juga analisis regresi linier berganda untuk melihat keterkaitan pengaruh antara indikator kesehatan lingkungan dengan kemiskinan yang terjadi di Indonesia.

\section{Metode Penelitian \\ 2.1 Data dan Variabel Penelitian}

Data yang digunakan dalam paper ini adalah data sekunder terkait indikator perumahan dan kesehatan lingkungan tahun 2018 di 34 provinsi di Indonesia [1]. Ada empat variabel yang digunakan yang terdiri dari 3 variabel bebas berupa indikator kesehatan lingkungan di Indonesia satu variabel tak bebas. Penjelasan keempat variabel tersebut disajikan dalam Tabel 1. 
Tabel 1 Variabel Penelitian

\begin{tabular}{|c|c|}
\hline Variabel & Penjelasan Variabel \\
\hline $\mathrm{X}_{1}$ & $\begin{array}{l}\text { Air minum layak (berkualitas) adalah air minum yang terlindung meliputi air ledeng (keran), } \\
\text { keran umum, hydrant umum, terminal air, penampungan air hujan (PAH) atau mata air dan } \\
\text { sumur terlindung, sumur bor atau sumur pompa, yang jaraknya minimal } 10 \text { meter dari } \\
\text { pembungan kotoran, penampungan limbah dan pembuangan sampah. Tidak termasuk air } \\
\text { kemasan, air dari penjual keliling, air yang dijual melalui tangki, air sumur dan mata air tidak } \\
\text { terlindung. }\end{array}$ \\
\hline $\mathrm{X}_{2}$ & $\begin{array}{l}\text { Fasilitas sanitasi layak adalah fasilitas sanitasi yang memenuhi syarat kesehatan, antara lain } \\
\text { klosetnya menggunakan leher angsa, tempat pembuangan akhir tinjanya menggunakan tangki } \\
\text { septik (septic tank) atau Sistem Pengolahan Air Limbah (SPAL), dan fasilitas sanitasi tersebut } \\
\text { digunakan oleh rumah tangga sendiri atau bersama dengan rumah tangga lain tertentu. } \\
\text { Variabel ini dapat menggambarkan tingkat kesejahteraan rakyat dari aspek kesehatan } \\
\text { (Kementerian Perencanaan Pembangunan Nasional/Badan Perencanaan Pembangunan } \\
\text { Nasional, 2007) }\end{array}$ \\
\hline $\mathrm{X}_{3}$ & $\begin{array}{l}\text { Rumah layak huni memiliki empat kriteria, yaitu kecukupan luas tempat tinggal minimal 7,2 } \\
\mathrm{m}^{2} \text { per kapita, memiliki akses air minum (acces to improved space), memiliki akses sanitasi } \\
\text { layak (access to adequate sanitasion), dan memenuhi syarat ketahanan bangunan (durable } \\
\text { housing) yaitu bahan bangunan utama atap rumah terluas bukan jerami/ijuk/daun- } \\
\text { daunan/rumbia/lainnya, bahan bangunan utama lantai terluas bukan berupa tanah atau lainnya, } \\
\text { serta bahan bangunan utama dinding rumah terluas bukan berupa bambu atau lainnya. Variabel } \\
\text { ini dapat digunakan untuk memantau peningkatan rumah tangga yang tinggal di hunian layak } \\
\text { dan terjangkau, sebagai upaya pengurangan penduduk yang tinggal di daerah kumuh, } \\
\text { permukiman liar, atau rumah yang tidak layak (Kementerian Perencanaan Pembangunan } \\
\text { Nasional/Badan Perencanaan Pembangunan Nasional, 2017) }\end{array}$ \\
\hline $\mathrm{Y}$ & $\begin{array}{l}\text { Kemiskinan dipandang sebagai ketidakmampuan dari sisi ekonomi untuk memenuhi } \\
\text { kebutuhan dasar (basic needs approach) makanan dan bukan makanan yang diukur dari sisi } \\
\text { pengeluaran. Pendekatan ini dapat dihitung melalui Headcount Index, yaitu persentase } \\
\text { penduduk miskin terhadap total penduduk. }\end{array}$ \\
\hline
\end{tabular}

\subsection{Analisis Cluster}

Metode yang digunakan dalam penelitian ini adalah analisis cluster (analisis gerombol). Analisis Cluster adalah teknik yang digunakan untuk mengklasifikasikan objek ke dalam kelompok yang relatif homogen yang disebut cluster [3]. Objek dalam tiap cluster cenderung memiliki kemiripan satu dengan lainnya, sedangkan antar cluster mempunyai sifat yang berbeda. Analisis cluster juga disebut analisis klasifikasi atau taksonomi numeric (numerical taxonomy). Analisis cluster pada prinsipnya digunakan untuk mereduksi data yaitu meringkas sejumlah variabel menjadi lebih sedikit dan menamakannya sebagai cluster.

Analisis cluster dapat dibagi menjadi dua jenis, yaitu Hierarchical Cluster dan K-Means Cluster (Nonhierarchical cluster)[4]. Pengelompokkan secara hierarki biasanya digunakan untuk jumlah sampel yang relatif sedikit. Sedangkan untuk data yang banyak dapat digunakan $K$-Means Cluster.

Tujuan pengelompokan ialah untuk mengelompokkan obyek yang mirip dalam cluster yang sama. Oleh karena itu beberapa ukuran diperlukan untuk mengakses seberapa mirip atau berbeda obyek-obyek tersebut. Pendekatan yang paling biasa ialah mengukur kemiripan dinyatakan dalam jarak (distance) antara pasangan obyek. Makin besar nilai ukuran kemiripan atau jarak antar dua buah obyek, makin besar pula perbedaan antara dua objek tersebut, sehingga cenderung untuk tidak menganggapnya ke dalam kelompok yang sama.

Terdapat beberapa cara dalam mengukur jarak, yaitu:

1. Menggunakan jarak Euclidean, yaitu jarak berupa akar kuadrat perbedaan nilai untuk tiap variabel.

Jika $x=\left(x_{1}, x_{2}, \ldots, x_{p}\right) \quad Y=\left(y_{1}, y_{2}, \ldots, y_{p}\right)$ maka

$$
D(x, y)=\sqrt{\left(x_{1}-y_{1}\right)^{2}+\left(x_{2}-y_{2}\right)^{2}+\ldots+\left(x_{p}-y_{p}\right)^{2}}
$$

2. Menggunakan jarak kuadrat Euclidean (squared Euclidean distance).

3. The city Block or Manhattan Distance antara dua objek merupakan jumlah nilai perbedaan mutlak untuk tiap variabel. Jarak ini juga disebut jarak Minkowski.

Jika $x^{\prime}=\left(x_{1}, x_{2}, \ldots, x_{p}\right) ; p$ adalah variable, maka $x_{1}{ }^{\prime}=\left(x_{i 1}, x_{i 2}, \ldots, x_{i p}\right)$ adalah kumpulan variabel pada obyek ke-i 


$$
d_{i j}=\left(\sum_{k=1}^{p} x_{i k}-y_{i k}\right)^{1 / r}
$$

dengan $\mathrm{d}_{\mathrm{ij}}$ adalah jarak antar dua obyek ke-i dan obyek ke-j.

Langkah-langkah yang dilakukan dalam pengelompokan:

1. Sampel yang diambil harus benar-benar bisa mewakili populasi.

2. Pengujian multikolinieritas untuk mengetahui ada tidaknya variabel independen yang memiliki kemiripan dengan variabel independen lainnya.

3. Transformasi data

Jika terdapat perbedaan nilai yang besar antar variabel yang dapat menyebabkan bias dalam analisis cluster maka data asli perlu ditransformasikan (standarisasi). Misalnya terdapat variabel dalam satuan puluhan dan ada dengan satuan ratusan. Perbedaan data yang besar akan menyebabkan perhitungan jarak menjadi tidak valid.

4. Analisis Cluster

Metode yang digunakan adalah metode hierarki (average Linkage) dengan teknik agglomerative dan ukuran jarak Euclidean. Langkah-langkah pengelompokkan dalam analisis cluster dengan metode hierarki mencakup tiga hal, yaitu:

a. Mengukur kesamaan jarak

Hal yang penting dalam penggerombolan adalah bagaimana mengkualifikasi ukuran kemiripan antar obyek.

b. Membentuk cluster secara hierarkis

Dalam metode ini menggunakan aglomerasi dimana tiap observasi pada mulanya dianggap sebagai cluster tersendiri sehingga terdapat cluster sebanyak jumlah observasi. Kemudian dua cluster yang terdekat kesamaannya digabung menjadi suatu cluster baru, sehingga jumlah cluster berkurang satu pada tiap tahap.

c. Melakukan interpretasi terhadap cluster yang terbentuk

Tahap akhir dari analisis cluster adalah menginterpretasikan dari cluster-cluster yang terbentuk.

\subsection{Analisis Regresi Berganda}

Metode yang digunakan dalam pendugaan Regresi Linier Berganda (RLB) adalah metode kuadrat terkecil. Adapun persamaan regresi linier berganda dalam penelitian dapat ditulis sebagai berikut:

$$
Y^{\prime}=a+b_{1} X_{1}+b_{2} X_{2}+b_{3} X_{3}+\varepsilon_{i}
$$

dimana $Y$ merupakan variabel tak bebas yaitu persentase penduduk miskin, $a$ menyatakan konstanta variabel $Y$ apabila variabel bebas sama dengan nol. Adapun $X_{1}, X_{2}, X_{3}$ merupakan variabel bebas yang secara berturutturut menyatakan proporsi air minum layak, proporsi sanitasi layak dan proporsi hunian layak.

Adapun asumsi klasik pada persamaan RLB adalah sebagai berikut:

1. Uji asumsi klasik normalitas atau sebaran data berdistribusi normal melalui uji kolmogorov smirnov one sampel test

2. Uji asumsi klasik non multikolinieritas yang digunakan untuk mengukur tingkat asosiasi (keeratan) hubungan/pengaruh antar variabel bebas tersebut melalui besaran koefisien korelasi (r). Variabel bebas dikatakan non multikolinieritas jika koefisien korelasi antar variabel bebas lebih kecil atau sama dengan 0,60. Atau dapat dilihat dari nilai VIF nya, yaitu apabila nilai VIF kurang dari 10, maka data tersebut nonmultikolinieritas.

3. Uji asumsi klasik heteroskedastisitas yaitu untuk melihat mengenai sama atau tidak varians dari residual dari observasi yang satu dengan observasi lainnya. Analisis uji ini dapat dilihat dari hasil output SPSS antara $\mathrm{Z}$ prediction (Zpred) dan nilai residualnya (Sred).

4. Uji asumsi klasik autokorelasi. Ukuran ada atau tidaknya masalah autokorelasi adalah dengan uji Durbin Watson(DW) dengan ketentuan terjadi autokorelasi positif jika DW di bawah -2 (DW $<-2)$ dan tidak terjadi autokorelasi jika DW berada di anatara -2 dan +2 atau $-2<\mathrm{DW}+2$

\section{Hasil dan Pembahasan}

\subsection{Gambaran Umum Kesehatan Lingkungan di Indonesia}

Di dalam [1], BPS mencatat capaian kesehatan lingkungan di Indonesia masih belum menunjukkan level yang memuaskan. Hal ini dapat dilihat dari berbagai indikator kesehatan lingkungan yang masih memperlihatkan 
belum optimalnya keadaan kesehatan lingkungan di Indonesia. Dilihat dari aspek porporsi air minum layak, Indonesia masih berada pada posisi kurang memuaskan, pasalnya pada tahun 2018 akses air minum layak baru sebesar 73,68 persen. Artinya, dari 100 rumah tangga di Indonesia, baru 74 rumah tangga yang dapat mengakses air minum layak, sedangkan sisanya yaitu 26 rumah tangga belum dapat mengakses air minum layak.

Dilihat dari sebarannya, masih terlihat kesenjangan dan ketimpangan yang terjadi di berbagai provinsi. Akses air minum layak terendah berada pada Provinsi Bengkulu (49,37 persen), Provinsi Lampung (56,78 persen) dan Provinsi Papua (58,35 persen). Sedangkan provinsi dengan akses air minum layak tertinggi berada pada Provinsi Bali (90,9 persen), DKI Jakarta (89,59 persen) dan Kalimantan Utama (88,30 persen).

Di sisi lain, fasilitas sanitasi layak di Indonesia juga masih tergolong sangat rendah. Pada tahun 2018, fasilitas sanitasi layak di Indonesia sebesar 69,27 persen. Artinya, dari 100 rumah tangga yang berada di Indonesia, terdapat 69 rumah tangga yang memiliki sanitasi layak, sedangkan sisanya 31 rumah tangga tergolong belum memiliki fasilitas sanitasi layak. Dari 34 provinsi yang ada, Provinsi Papua merupakan provinsi yang berada pada posisi terbawah yaitu sebesar 33,75 persen. Artinya, hanya sepertiga rumah tangga yang berada pada Provinsi Papua dapat menikmati fasilitas sanitasi layak. Posisi kedua terbawah adalah Provinsi Bengkulu yaitu sebesar 44,31 persen. Kemudian Provinsi Nusa Tenggara Timur dan Provinsi Lampung masing-masing berada pada urutan ketiga dan keempat terbawah yakni sebesar 50,72 persen dan 52,48 persen.

Sementara itu, provinsi yang memiliki fasilitas akses sanitasi terbaik adalah Provinsi Bali yaitu sebesar 91,14 persen. Kemudian disusul Provinsi DKI Jakarta yang memiliki akses fasilitas sanitasi layak sebesar 90,73 persen. Sedangkan posisi ketiga berada pada Provinsi DI Yogyakarta sebesar 88,92 persen.

Selain hal di atas, indikator kesehatan lingkungan juga dapat dilihat dari banyaknya persentase rumah tangga yang memiliki hunian layak. Pada variabel ini, capaiannya sangat bagus yaitu rumah tangga yang memiliki hunian layak di Indonesia sebesar 98,6 persen. Artinya, dari 100 rumah tangga yang ada di Indonesia, sekitar 99 rumah tangga yang memiliki hunian layak, sedangkan hanya satu rumah tangga yang memiliki hunian tidak layak. Secara rata-rata, capaian hunian layak menunjukkan angka yang sangat bagus, namun demikian, masih ada beberapa provinsi yang perlu ditingkatkan dalam pembangunan hunian layak. Provinsi tersebut adalah Nusa Tenggara Timur, dan Sulawesi Barat dengan capaian hunian layak masing-masing baru sebesar 94,1 persen dan 95,5 persen.

Untuk persentase penduduk miskin, tahun 2018 merupakan pertama kali dalam sejarah Indonesia dengan persentase penduduk miskin sebesar satu digit, yaitu sebesar 9,8 persen. Tren persentase penduduk miskin di Indonesia dari tahun ke tahun selalu menunjukkan grafik yang menurun. Namun demikian, kesenjangan dan ketimpangan antar provinsi masih dapat terlihat jelas. Adanya kesenjangan dan ketimpangan tersebut dapat dilihat dari tingginya persentase penduduk miskin di berbagai Wilayah Indonesia Bagian Timur seperti Provinsi Papua, Papua Barat, Nusa Tenggara Timur dan Maluku. Keempat provinsi tersebut memiliki persentase penduduk miskin masing-masing sebesar 27,7 persen; 23,0 persen; 21,4 persen dan 18,1 persen. Sedangkan provinsi dengan pendududk miskin terendah adalah DKI Jakarta (3,6 persen), Bali (4,0 persen), dan Kalimantan Selatan (4,5 persen).

\subsection{Pengelompokkan Berdasarkan Indikator Kesehatan Lingkungan}

Hasil pengelompokkan dengan metode Clustering Hierarchical adalah sebagai berikut:

1. Jumlah anggota kelompok

\begin{tabular}{cc} 
Tabel 2 Jumlah Anggota Kelompok (Cluster) \\
\hline Kelompok & $\begin{array}{c}\text { Jumlah Anggota } \\
\text { Kelompok (Provinsi) }\end{array}$ \\
\hline$(1)$ & $(2)$ \\
\hline 1 & 3 \\
\hline 2 & 7 \\
\hline 3 & 24 \\
\hline
\end{tabular}

Pengelompokkan provinsi di Indonesia berdasarkan indikator kesehatan lingkungan terbagi menjadi 3 kelompok. Kelompok pertama terdiri dari 3 provinsi, kelompok kedua terdiri dari 7 provinsi dan kelompok ketiga terdiri dari 24 provinsi.

2. Anggota kelompok dan karakteristik kelompok

a. Kelompok pertama terdiri dari Provinsi Bengkulu, Lampung dan Papua. Karakteristiknya adalah provinsi dengan angka akses air minum dan sanitasi terendah dibandingkan dengan kelompok cluster lainnya. 
b. Kelompok kedua terdiri dari Provinsi DKI Jakarta, Bali, Kalimantan Timur, Sulawesi Selatan, Kepulauan Riau, DI Yogyakarta dan Kepulauan Bangka Belitung. Kelompok ini memiliki karakteristik indikator kesehatan lingkungan terbaik dibandingkan dengan kelompok pertama dan ketiga. Secara ratarata, nilai akses air minum, sanitasi dan hunian layak tertinggi yaitu masing-masing sebesar 81,53 persen, 85,76 persen dan 99,31 persen.

c. Kelompok ketiga terdiri dari Jawa Barat, Sulawesi Tengah, Maluku Utara, Aceh, Sumatera Selatan, Jambi, Kalimantan Selatan, Sulawesi Barat, Sumatera Barat, Kalimantan Barat, Kalimantan Tengah, Nusa Tenggara Timur, Riau, Sulawesi Tenggara, Jawa Timur, Maluku, Banten, Sumatera Utara, Nusa Tenggara Barat, Jawa Tengah, Papua Barat, Sulawesi Utara, Gorontalo dan Kalimantan Utara. Kelompok ini merupakan kelompok pertengahan antara kelompok pertama dan kedua. Secara umum, nilai ketiga variabel mendekati nilai Nasional, yaitu masing-masing sebesar 72,71 persen; 66,38 persen dan 98,22 persen.

Gambaran singkat mengenai karakteristik ketiga kelompok berdasarkan kesehatan lingkungan disajikan pada Tabel 3.

Tabel 3 Karakteristik kelompok berdasarkan kesehatan lingkungan

\begin{tabular}{lccc}
\hline \multirow{2}{*}{\multicolumn{1}{c}{ Variabel }} & \multicolumn{3}{c}{ Kelompok } \\
\cline { 2 - 4 } & $\mathbf{1}$ & $\mathbf{2}$ & $\mathbf{3}$ \\
\hline Akses air minum layak & 54,83 & 81,53 & 72,71 \\
\hline Sanitasi layak & 43,51 & 85,76 & 66,38 \\
\hline Hunian layak & 98,26 & 99,31 & 98,22 \\
\hline Angka Kemiskinan & 18,77 & 6,61 & 11,04 \\
\hline
\end{tabular}

\subsection{Analisis Regresi Linier Berganda}

Setelah variabel bebas diregresikan dengan metode kuadrat terkecil, diperoleh hasil ANOVA seperti yang disajikan pada Tabel 4 sebagai berikut.

Tabel 4 Uji Simultan Regresi Linier Berganda

\begin{tabular}{|c|c|c|c|c|c|c|}
\hline \multicolumn{7}{|c|}{ ANOVAC } \\
\hline \multicolumn{2}{|c|}{ Model } & $\begin{array}{l}\text { Sum of } \\
\text { Squares }\end{array}$ & df & Mean Square & $\mathrm{F}$ & Sig. \\
\hline \multirow[t]{3}{*}{1} & Regression & 347,889 & 3 & 115,963 & 4,616 &, $009^{9}$ \\
\hline & Residual & 753,706 & 30 & 25,124 & & \\
\hline & Total & 1101,595 & 33 & & & \\
\hline \multirow[t]{3}{*}{2} & Regression & 341,524 & 2 & 170,762 & 6,965 &, $003^{b}$ \\
\hline & Residual & 760,070 & 31 & 24,518 & & \\
\hline & Total & 1101,595 & 33 & & & \\
\hline \multicolumn{7}{|c|}{ a. Predictors: (Constant), rumah_layak_huni, air_minum_layak, sanitasi_layak } \\
\hline \multicolumn{7}{|c|}{ b. Predictors: (Constant), rumah_layak_huni, sanitasi_layak } \\
\hline \multicolumn{7}{|c|}{ c. Dependent Variable: kemiskinan } \\
\hline
\end{tabular}

Hasil estimasi menunjukkan bahwa secara simultan melalui Uji F, ketiga variabel bebas yaitu air minum layak, sanitasi layak dan hunian layak secara bersama-sama mempunyai pengaruh terhadap variabel tak bebas yaitu persentase angka kemiskinan di Indonesia. Hal ini terlihat dari nilai probabilitas signifikansi sebesar 0,009 yang lebih kecil dari taraf signifikansi yang ditentukan yaitu sebesar $\alpha=5 \%$. Namun demikian, model terbaik akan terbentuk apabila variabel akses air minum layak dikeluarkan dari model, sehingga nilai signifikansi menjadi 0,003 .

Sedangkan untuk melihat pengaruh masing-masing variabel bebas (parsial) digunakan uji t-test. Dengan tingkat kepercayaan $95 \%(\alpha=5 \%)$, maka uji hipotesisnya adalah sebagai berikut:

$H_{0}: b_{i}=0$ (fasilitas sanitasi layak dan hunian layak secara parsial tidak berpengaruh terhadap kemiskinan di Indonesia), $i=1,2,3$

$H_{a}: b_{i} \neq 0$ (fasilitas sanitasi layak dan hunian layak secara parsial berpengaruh terhadap kemiskinan di Indonesia), $i=1,2,3$

Diperoleh output SPSS sebagai berikut: 
Tabel 5 Uji t-test pada Regresi Linier Berganda Coefficients $^{\mathrm{a}}$

\begin{tabular}{|c|c|c|c|c|c|c|}
\hline \multirow[b]{2}{*}{ Model } & & \multicolumn{2}{|c|}{$\begin{array}{l}\text { Unstandardized } \\
\text { Coefficients }\end{array}$} & \multirow{2}{*}{$\begin{array}{c}\begin{array}{c}\text { Standardized } \\
\text { Coefficients }\end{array} \\
\text { Beta }\end{array}$} & \multirow[b]{2}{*}{$t$} & \multirow[b]{2}{*}{ Sig. } \\
\hline & & B & Std. Error & & & \\
\hline \multirow[t]{4}{*}{1} & (Constant) & 159,451 & 82,005 & & 1,944 &, 061 \\
\hline & air_minum_layak &, 072 & , 142 & 115 &, 503 &, 618 \\
\hline & sanitasi_layak & -196 & 109 &,- 440 & $-1,797$ & 082 \\
\hline & rumah_layak_huni & $-1,427$ & 855 & -289 & $-1,670$ &, 105 \\
\hline \multirow[t]{3}{*}{2} & (Constant) & 163,341 & 80,651 & & 2,025 &, 052 \\
\hline & sanitasi_layak & -157 &, 076 &,- 353 & $-2,062$ &, 048 \\
\hline & rumah_layak_ huni & $-1,440$ & 844 &,- 292 & $-1,707$ &, 098 \\
\hline
\end{tabular}

a. Dependent Varizble: kemiskinan

Hasil $t_{\text {hitung }}$ variabel fasilitas sanitasi layak sebesar 0,048 yang lebih kecil dari alpa yang digunakan $(\alpha=$ $5 \%$ ). Hal ini menunjukkan bahwa variabel fasilitas sanitasi layak berpengaruh terhadap persentase kemiskinan yang terjadi di Indonesia dengan asumsi variabel lainnya tetap. Sedangkan untuk variabel rumah layak huni, secara statistik tidak berpengaruh terhadap persentase kemiskinan di Indonesia. Adapun model regresi yang terbentuk adalah:

$$
Y=163,341-0,157 X_{2}-1,440 X_{3}
$$

Berdasarkan Persamaan (4) maka peningkatan persentase fasilitas sanitasi layak sebesar satu satuan akan menurunkan persentase kemiskinan sebesar 0,157, dengan asumsi variabel variabel rumah layak huni tetap. Variabel ini paling signifikan memengaruhi persentase kemiskinan di Indonesia, meskipun konstanta kecepatan dalam menurunkan kemiskinan di Indonesia relatif kecil dibandingkan variabel hunian layak. Adapun Peningkatan persentase hunian layak sebesar satu satuan, maka hal tersebut akan menurunkan persentase kemiskinan sebesar 1,44, dengan asumsi variabel sanitasi layak tetap. Secara statistik, dengan $\alpha=5 \%$, variabel ini memang tidak signifikan memengaruhi persentase kemiskinan, namun konstanta dalam penurunan persentase kemiskinan lebih besar dibandingkan dengan variabel fasilitas sanitasi layak.

\section{Kesimpulan}

Pengelompokkan Provinsi berdasarkan indikator kesehatan lingkungan tahun 2018 menghasilkan tiga kelompok wilayah yang berbeda. Kelompok pertama merupakan Provinsi dengan karakteristik kesehatan ligkungan terburuk yaitu Provinsi Bengkulu, Lampung dan Papua. Kelompok kedua yang terdiri dari 7 provinsi merupakan provinsi dengan karakteristik kesehatan lingkungan terbaik dibandingkan kelompok lainnya. Sedangkan untuk kelompok ketiga merupakan kelompok pertengahan dengan jumlah anggota terbanyak yaitu 24 Provinsi. Selain itu, ada juga kaitannya antara indikator kesehatan lingkungan dengan kemiskinan yang terjadi di Indonesia. Namun hanya variabel fasilitas sanitasi layak yang berpengaruh signifikan terhadap kemiskinan yang terjadi di Indonesia. Semakin bagus fasilitas sanitasi maka persentase kemiskinan semakin rendah.

\section{Ucapan Terima Kasih}

Terima kasih penulis ucapkan kepada Ibu Wintarti Dyah Indriani, SE Selaku Kepala BPS Kabupaten Pesawaran dan ibu Lusi Oktari, S.Si Selaku Kepala Seksi Statistik Distribusi yang telah membimbing penulis dalam menyelesaikan makalah ini.

\section{Daftar Pustaka:}

[1] Badan Pusat Statistik. 2018. Indikator Perumahan dan Kesehatan Lingkungan Tahun 2018. Badan Pusat Statistik, Jakarta

[2] Ustun, A.P., Bonjour S., and Corvalan, C. 2008. The Impact of The Environment on Health by Country : a Meta-synthesis. Enviromental Health, 7:7. Pp 1-10.

[3] Suprapto, J. 2004. Analisis Multivariat: Arti dan Interpretasi. Jakarta:Rineka Cipta.

[4] Liao, T.W. 2005. Clustering of time series data-a survei. Pattern Recognit. 38, pp 1857-1874.

[5] Jain, A.K. 2010. Data clustering: 50 years beyond k-means. Pattern Recognit. Lett. 31, pp 651-666.

[6] Tuffery, S. 2011. Data mining and statistics for decision making. Wiley, Sussex.

[7] Jain, A.K., Murty, M.N., and Flynn, P.J., 1999. Data clustering: a review. ACM Comput. Surv. 31(3), $262-$ 323. 